\begin{tabular}{|c|c|c|c|c|c|c|}
\hline \multirow{4}{*}{ Impact Factor: } & ISRA (India) & $=3.117$ & SIS (USA) & $=0.912$ & ICV (Poland) & $=6.630$ \\
\hline & ISI (Dubai, UAE & $=0.829$ & РИНЦ (Russia) & $=0.156$ & PIF (India) & $=1.940$ \\
\hline & GIF (Australia) & $=0.564$ & ESJI (KZ) & $=8.716$ & IBI (India) & $=4.260$ \\
\hline & JIF & $=1.500$ & SJIF (Morocco) & $=5.667$ & OAJI (USA) & $=0.350$ \\
\hline
\end{tabular}

\section{SOI: 1.1/TAS DOI: 10.15863/TAS International Scientific Journal Theoretical \& Applied Science}

p-ISSN: 2308-4944 (print) e-ISSN: 2409-0085 (online)

Year: $2019 \quad$ Issue: $05 \quad$ Volume: 73

Published: $30.05 .2019 \quad$ http://T-Science.org

SECTION 21. Pedagogy. Psychology. Innovations in the field of education.
QR - Issue

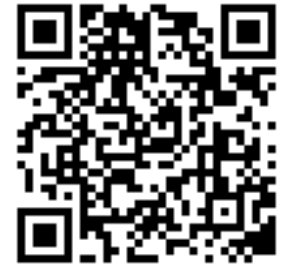

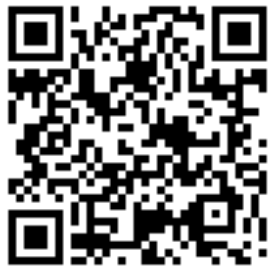

M. Inamova

Candidate of Pedagogical Sciences, Associate Professor of Foreign Languages Department Namangan Engineering Construction Institute

Feruza Dadabayeva Teacher of the department of foreign languages between faculties, Namangan State University

Nargiza Karimova Teacher of the department of foreign languages between faculties, Namangan State University

\title{
THE ROLE OF PEDAGOGY IN THE EDUCATION OF A MATURE PERSON
}

Abstract: The subject of pedagogy is the study of the essence of the formation and development of the human personality and the development on this basis of the theory and methodology of education as a specially organized pedagogical process. This article discusses the functions of pedagogy in the education of youth.

Key words: person, perfect person, pedagogy, education, method, pedagogical means.

Language: English

Citation: Inamova, M., Dadabayeva, F., \& Karimova, N. (2019). The role of pedagogy in the education of a mature person. ISJ Theoretical \& Applied Science, 05 (73), 639-643.

Soi: http://s-o-i.org/1.1/TAS-05-73-100 Doi: crossef https://dx.doi.org/10.15863/TAS.2019.05.73.100

\section{Introduction}

Each science in the same object of study distinguishes its subject of study - one or another form of being of the objective world, this or that side of the development of nature and society. Education as a complex, objectively existing phenomenon is studied in many sciences. Historical materialism, for example, considers education as a particular moment in the development of society, its productive forces and production relations; history - as a private moment in the history of class struggle and class politics; psychology - in connection with the study of the formation of the personality of a developing person. The independence of any science is determined, first of all, by the presence of a special, own subject of study, the presence of such a subject, which is not specifically studied by any other scientific discipline. In the general system of sciences, in the general system of "things and knowledge," pedagogy acts as the only science that has as its object the education of man. The study of every science begins with the clarification of such questions: how did this science come about and did it develop, and what specific problems does it explore? In fact, each science has its own history and a fairly definite aspect of natural or social phenomena, the study of which it is engaged, and the knowledge of which is of great importance for understanding its theoretical foundations.

\section{Materials and Methods}

Without this, it could not develop. Therefore, the number of educational institutions is growing, the network of public schools expanding to provide necessary training for children is being expanded, special educational institutions for teacher training are being opened, and pedagogy is being taught as a special scientific discipline. All this gave a great impetus to the development of pedagogical theory. Having emerged as a science about the upbringing of children and young people, pedagogy, as the boundaries of upbringing and the scope of subjective factors in the life of society expand, become more and more the science of general patterns of educational impact on people of all ages. Developing, every science enriches its theory, is filled with new content and carries out the differentiation of its research. This process also affected pedagogy. Currently, the concept of "pedagogy" refers to the whole system of 


\begin{tabular}{|c|c|c|c|c|c|c|}
\hline \multirow{4}{*}{ Impact Factor: } & ISRA (India) & $=3.117$ & SIS (USA) & $=0.912$ & ICV (Poland) & $=6.630$ \\
\hline & ISI (Dubai, UAI & $=0.829$ & РИНЦ (Russia & $=0.156$ & PIF (India) & $=1.940$ \\
\hline & GIF (Australia) & $=0.564$ & ESJI (KZ) & $=8.716$ & IBI (India) & $=4.260$ \\
\hline & JIF & $=1.500$ & SJIF (Morocce & $=5.667$ & OAJI (USA) & $=0.350$ \\
\hline
\end{tabular}

pedagogical sciences. Pedagogy as a science is divided into a number of independent pedagogical disciplines: 1. General pedagogy, explores the basic laws of human education; reveals the essence, goals, objectives and patterns of education, its role in society and the development of the individual, the process of education and training. 2. Age pedagogy, studying the features of education of people at various stages of age development; it is subdivided into prepositions (vocational, higher education, etc.);3. Special pedagogy - defectology, studying the features of development, training and education of abnormal children. Which in turn breaks down into a number of industries: the education of and education of deaf and deaf children is dealt with by deaf-pedagogy, blind and visually impaired - by typhoid-pedagogy, mentally retarded - by oligophreno pedagogy, by children with speech disorders with normal hearing speech therapy; 4. A private technique that explores the specificity of the application of general laws of study to the teaching of a particular subject (foreign language, mathematics, biology, physics, chemistry, etc.);5. The history of pedagogy, studying the development of pedagogical ideas and practices of education in various historical eras. The branches of pedagogical science, such as vocational education pedagogy, higher school pedagogy, military pedagogy, and corrective-labor pedagogy, are developing intensively as independent. Such parts of pedagogy as school science, the pedagogy of family education, the pedagogy of children's and youth organizations, the pedagogy of cultural and educational work are taking shape.

The process of versatile interpenetration of sciences, the development of a comprehensive study of pedagogical phenomena objectively require an organic connection between pedagogy and other sciences. Pedagogy develops, strengthening and improving its ties with philosophy, sociology, ethics, aesthetics, psychology, anatomy and human physiology, hygiene, ethnography, mathematics, cybernetics, etc.In close relationships, pedagogy is with a common, age-related and pedagogical psychology. Psychology reveals the patterns of mental development of people in different age periods, the mechanism of mental changes under the influence of training and education. Its ideas are widely used in the development of the organization of the cognitive activity of students in the learning process. The connection between pedagogy and social psychology, which studies the relationships, feelings, moods, opinions, assessments, character traits and features of the mental state of people in different social conditions, has been developed.

Exceptionally valuable knowledge of the nature of human physical development, pedagogy, is equipped with general and age physiology, which constitutes the natural scientific basis of training and education. The study of conditioned reflex activity helps to reveal the scientific basis of the changes that occur in a person under the influence of external influences and are associated with the formation of skills, habits and habits. New, additional opportunities for the study of the processes of teaching and upbringing in front of pedagogy are opened up by a rapidly developing field of knowledge, which has received the name of management theory. Having emerged in the system of social sciences, it uses the achievements of cybernetics, which has revealed the most general laws governing the management of complex dynamic systems. At the same time, however, it must be borne in mind that cybernetics studies control processes irrespective of the qualitative nature of self-governing systems; Upbringing is a system with deep qualitative specificity, its own specific laws that are inaccessible to cybernetics. The independence of any science is not whether it uses or does not use the data of other sciences. Soviet pedagogy uses materials and data from related sciences to solve its problems, on the basis of rigorous selection and identifying the boundaries of their application.

So, the pedagogical science is a clot of the centuries-old experience of training and education of the younger generations. Pedagogical science is the result of many years of research into the laws governing the formation of a comprehensively and harmoniously developed personality. Knowledge of pedagogical science helps in each case to choose the best pedagogical solutions. A long-standing argument about what pedagogy is - a science or an art - is divided into practice. Testing with practice confirms many times: without a deep knowledge of the science of education, the art of educating does not develop. Knowledge of the patterns of training and education, mastering the methods of the pedagogical process is the basis of teaching skills. Mastering pedagogy should be approached as a scientific and cognitive activity, on the basis of which pedagogical art can and should develop as an integral element of pedagogical activity. And not everyone can be a teacher. This should be a person who has a vocation, a call, an inner awareness that this is his path - the path of search, constant anxiety, the path of doubt of the extraordinary demandingness of oneself, the path of hard, everyday work.

An essential condition for the separation and functioning of any science is the presence of a categorical apparatus in it. What are the basic concepts (categories) of pedagogical science? The place of pedagogy in the system of human sciences is determined by the fact that it explores the patterns of development, formation, upbringing, education and training of the individual. Human development is the process of formation of his personality under the influence of external and internal, controlled and uncontrolled social and natural factors. According to the dialectical-materialistic concept, the development 


\begin{tabular}{|c|c|c|c|c|c|c|}
\hline \multirow{4}{*}{ Impact Factor: } & ISRA (India) & $=3.117$ & SIS (USA) & $=0.912$ & ICV (Poland) & $=6.630$ \\
\hline & ISI (Dubai, UAE & $=0.829$ & РИНЦ (Russia & $=0.156$ & PIF (India) & $=1.940$ \\
\hline & GIF (Australia) & $=0.564$ & ESJI (KZ) & $=8.716$ & IBI (India) & $=4.260$ \\
\hline & JIF & $=1.500$ & SJIF (Morocce & $=5.667$ & OAJI (USA) & $=0.350$ \\
\hline
\end{tabular}

of an individual (ontogenesis) is a process of quantitative and qualitative changes, naturally occurring in the anatomical and physiological structure of the human body. Soviet pedagogy does not exclude the influence of heredity on human development. It is known that heredity reflects the characteristics laid down in the human genetic program, which are transmitted from parents to children. These are the color of skin, eyes, hair, and physique, and features of the nervous system, as well as the makings of speech, thinking, etc.

The heredity of children is significantly affected by the state of mental health and the lifestyle of the parents. For example, alcoholism, drug addiction, and substance abuse of parents negatively affect the mental abilities of children. Development is progress, the transition from lower to higher, from simple to complex, from imperfect to more perfect. There are mental, physical and general personality development. Under the mental development understand the development of intelligence, will, emotions, as well as the needs, abilities and nature of the individual. Physical development is the development of an organism, muscles, mobility of joints, etc. The overall development is the development of mental, physical, moral and other personality traits. The personality of a person is the result of the action and interaction of various factors. Some of them act more or less independently of the will and consciousness of people. These include the biological nature of man, social relations, phenomena of social psychology, lifestyle, geographical environment, conditions of the microenvironment. Others are more or less dependent on the will and consciousness of people. This is the ideology, the activity of the state, public institutions.

The third group of factors involves organized development. All of these factors combine to provide personality formation. Hence, the formation of a person's personality is the process of its formation under the influence of numerous factors, natural and social, external and internal, acting spontaneously and according to certain rules, using certain means. Education - is one of the factors for the formation of personality. It consists in the fact that people want to achieve a certain goal by some means or another - to develop and form certain qualities in a pupil. The qualitative peculiarity of upbringing, in contrast to other factors of personality formation, consists in the fact that the educator consciously sets a certain goal and, striving to achieve this goal, finds the means leading to its realization. Thus, upbringing is a social relation in which some people influence others in order to shape personality. Where there is upbringing, the driving forces of development, age, typological and individual characteristics of the educated are taken into account. Where there is upbringing, the positive power of the microenvironment is used to its full potential and the negative effects of the microenvironment are weakened. Where there is upbringing, a person is previously capable of selfeducation.

The process of education is aimed at the formation of socially important personal qualities, at creating and expanding the circle of its relations to the world around us - towards society, towards people, towards oneself. The wider, more diverse and deeper the system of relations of the individual to different aspects of life, the richer its own spiritual world. Among the most important and most common pedagogical concepts are also education and training. By education, we understand this aspect of education, which consists in mastering the system of scientific and cultural values accumulated by mankind, in mastering the system of cognitive skills and abilities, forming on their basis worldview, morality, behavior, moral and other personality qualities, developing its creative powers abilities, preparation for public life, for work. The content of education includes all elements of social experience. Depending on the goals, nature and level of training, there are secondary, general, polytechnic, vocational and higher education. The knowledge, skills and abilities necessary for every person are provided by the secondary school. The knowledge, skills and abilities required by an employee of a particular profession are acquired in special educational institutions.

The subject of pedagogy is the study of the essence of the formation and development of the human personality and the development on this basis of the theory and methodology of education as a specially organized pedagogical process.

The pedagogical branch of knowledge is almost the oldest and in essence is inseparable from the development of society. The social progress of mankind became possible only because each new generation of people entering into life took possession of the productive, social and spiritual experience of their ancestors and, enriching it, transferred it to its descendants in a more developed form. The more developed and complicated the production, the more scientific knowledge accumulated, the more important was the special preparation of the younger generations for life, the more urgent became the need for their specially organized upbringing - in the purposeful transfer of the experience of mankind to them.

Education and upbringing turned into an objective need of society and became the most important prerequisite for its development. At a certain stage of development. At a certain stage of development of human society, in particular, in the late period of the slave system, when production and science have reached a considerable development, education is singled out as a special social function, i.e. there are special educational institutions, there are people whose profession is the education and upbringing of children. 


\begin{tabular}{|c|c|c|c|c|c|c|}
\hline \multirow{4}{*}{ Impact Factor: } & ISRA (India) & $=3.117$ & SIS (USA) & $=0.912$ & ICV (Poland) & $=6.630$ \\
\hline & ISI (Dubai, UAI & $=0.829$ & РИНЦ (Russia & $=0.156$ & PIF (India) & $=1.940$ \\
\hline & GIF (Australia) & $=0.564$ & ESJI (KZ) & $=8.716$ & IBI (India) & $=4.260$ \\
\hline & JIF & $=1.500$ & SJIF (Morocco & $=5.667$ & OAJI (USA) & $=0.350$ \\
\hline
\end{tabular}

From ancient Greece, the origin and the term pedagogy, which is entrenched as the name of the science of education, also derives its origin.

In ancient Greece, the teachers were slaves, whom the aristocrats instructed to look after the children, to accompany them to school. The Greek word peydagos (peyda - child, gogos - news) means the teacher. Later, teachers began to be called people who were engaged in the education and upbringing of children. From this word was called the science of education - pedagogy.

The object of cognition in pedagogy is a person developing as a result of educational relations. The subject of pedagogy is educational relations that ensure human development.

Pedagogy is the science of educational relations that arise in the process of interrelationship between upbringing, education and training with selfeducation, self-education and self-education and aimed at human development. Pedagogy can be defined as the science of translating the experience of one generation into the experience of another.

Pedagogy is the science of how to educate a person, how to help him become a spiritually rich, creatively active and completely satisfied life, find a balance with nature and society.

Pedagogy is sometimes seen as a science and as an art. When it comes to education, it must be borne in mind that it has two aspects - theoretical and practical. The theoretical aspect of education is the subject of scientific pedagogical research. In this sense, pedagogy acts as a science and represents a set of theoretical and methodological ideas on issues of education.

Another matter is practical educational activity. Its implementation requires the teacher to master appropriate skills and skills for education, which can reach the level of pedagogical art.

The subject of pedagogy is the study of the essence of the formation and development of the human personality and the development on this basis of the theory and methodology of education as a specially organized pedagogical process.

Pedagogy examines the following problems:

- Study of the essence and laws of development and formation of the personality and their influence on upbringing;

- Definition of the goals of upbringing;

- Development of educational content;

- Research and development of methods of education.

In any science, categories play a leading role, they permeate all scientific knowledge and, as it were, bind it into an integral system.
Education - a social, purposeful creation of conditions (material, spiritual, organizational) for the assimilation of a new generation of socio-historical experience in order to prepare it for social life and productive work. The category of "upbringing" is one of the main ones in pedagogy. They distinguish education in a broad social sense, including influence on the personality of society as a whole, and education in a narrow sense - as a purposeful activity that forms a system of qualities of the individual, views and beliefs. Education is often treated as a solution to a particular educational task. For example, the upbringing of a creative personality requires the teacher to understand the methodological and psychological-pedagogical aspects of educational, research and labor activity, the logic of educational activities to develop the abilities of the individual. The teacher needs an understanding of the essence and laws of the specialist, which he prepares, and the essence and logic of his own professional and pedagogical activity in the training and education of such a specialist. Thus, upbringing is the formation of a person 1) certain relationships to objects, phenomena of the surrounding world; 2) world outlook; 3) behavior. One can single out the types of upbringing (mental, moral, physical, labor, aesthetic, etc.).

\section{Conclusion}

Pedagogy examines the essence of upbringing, its patterns, trends and development prospects, develops the theories and technologies of upbringing, determines its principles, content, forms and methods.

Education - a concrete historical phenomenon, closely related to the socio-economic, political, and cultural level of society and the state.

The development of each person is provided by mankind through education, passing on its own experience and experience of previous generations.

Education for the sake of the happiness of a child is such a humanistic sense of pedagogical works. Sukhomlinsky, and his practical work is a convincing proof that without faith in the child's possibilities, without trust in him, all pedagogical wisdom, all methods and methods of teaching and upbringing are untenable.

The basis of the success of the teacher, he believed, is spiritual wealth, and the generosity of his soul, the upbringing of the senses and the high level of the general emotional culture, the ability to penetrate deeply into the essence of the pedagogical phenomenon. 


\begin{tabular}{llllll} 
& ISRA (India) $=\mathbf{3 . 1 1 7}$ & SIS (USA) & $=\mathbf{0 . 9 1 2}$ & ICV (Poland) & $=\mathbf{6 . 6 3 0}$ \\
Impact Factor: & ISI (Dubai, UAE) $=\mathbf{0 . 8 2 9}$ & PUHL (Russia) $=\mathbf{0 . 1 5 6}$ & PIF (India) & $=\mathbf{1 . 9 4 0}$ \\
& GIF (Australia) $=\mathbf{0 . 5 6 4}$ & ESJI (KZ) & $=\mathbf{8 . 7 1 6}$ & IBI (India) & $=\mathbf{4 . 2 6 0}$ \\
& JIF & $\mathbf{1 . 5 0 0}$ & SJIF (Morocco) $=\mathbf{5 . 6 6 7}$ & OAJI (USA) & $\mathbf{0 . 3 5 0}$ \\
\hline
\end{tabular}

\section{References:}

1. Karimbaeva, S. I., et al. (2016). Urbanizatsiyafaktor obshchestvennogo razvitiya. Vysshaya shkola, №. 8, pp. 76-77.

2. Muxiddinova, X. G. (2018). The role of information in the development of the society. Ekonomika $i$ sotsium, №. 9, pp. 45-47.

3. Dexqonova, S., \& Muxiddinova, X. G. (2017). Relationship and interaction of rights and morals. Teoriya i praktika sovremennoy nauki, №. 5, pp. 15-17.

4. Muxiddinova, X. G. (2017). Self-evaluation and meaning of human life. Ekonomika i sotsium, №. 4, pp. 29-31.

5. Tashbayeva, G. Y., \& Yuldashev, O. (2017). Amir temur: source of power and development for the future. Ekonomika i sotsium, №. 4, pp. 3740.

6. Tashbayeva, G. Y. (2018). Al xorazmiy is a great uzbek mathematician. Ekonomika $i$ sotsium, №. 2, pp. 67-69.

7. Tashbaeva, G. Y. (2018). Rol" dukhovnosti v vospitanii dukhovno razvitoy molodezhi. Ekonomika i sotsium, №. 2, pp. 449-450.

8. Dexqonova, S. E. (2017). Historical forms and manifestations: theological representations and interpretations of religious values. Teoriya $i$ praktika sovremennoy nauki, №. 4, pp. 5-8.

9. Dexqonova, S., \& Muxiddinova, X. G. (2017). Relationship and interaction of rights and morals. Teoriya i praktika sovremennoy nauki, №. 5, pp. 15-17.

10. Urinboev, K. B., \& Nurmatov, A. R. (2017). Novye pedagogicheskie tendentsii i problemy sovremennogo sotsiuma. Teoriya $i$ praktika sovremennoy nauki, №. 4, pp. 812-815.

11. O'rinboyev, X. B. (2017). View of spiritual threats in the context of globalization. Teoriya $i$ praktika sovremennoy nauki, №. 4, pp. 34-37.

12. Sotiboldiev, G. O., \& Khaydarov, M. T. (2016). Sotsial'no-ekonomicheskoe polozhenie Kokandskogo khanstva v epokhu Norbutabiya (1763-1798). apriori. Seriya: Gumanitarnye nauki, №. 3 .

13. Sotiboldiyev, G. O. (2017). Domestic policy of the kokand in the norbutabiya era (1763-1798). Teoriya i praktika sovremennoy nauki, №. 4, pp. 45-48.

14. Topildiev, N. R. (2018). Politicheskaya situatsiya Kokandskogo khanstva v 50-60-kh godakh XIX veka. innovatsionnoe razvitie: potentsial nauki i sovremennogo obrazovaniya. pp. 69-71.

15. Isxakov, B. B. (2017). The role of ecological culture in family ceremony (as examples uzbeks in fergana valley). Teoriya $i$ praktika sovremennoy nauki, №. 5, pp. 28-31.

16. Mamazhonova, G. K. Mezhreligioznoe soglasie kak odin iz osnovnykh faktorov bezopasnosti $\mathrm{v}$ tsentral"noy azii. Teoriya $i$ praktika sovremennoy nauki, №. 5, p. 483.

17. Urinboev, K. B., \& Mamazhonova, G. K. (2017). Samotsennost" i smysl chelovecheskoy zhizni. Teoriya i praktika sovremennoy nauki, №. 3, pp. 741-743. 